\title{
Coal Characterisation and Design for Fossil Fuel Fired Boiler in Thermal Power Plants
}

\author{
Siddhartha, Raj Kumar \\ Mechanical Engineering Department, \\ YMCA University of Science and Technology, \\ Zakir Nagar, Faridabad 121006, Haryana, India \\ E-Mail: mailsiddhartha08@gmail.com
}

\begin{abstract}
Coal is a highly heterogeneous in nature and requires several analytical techniques for its characterisation so as to accurately predict its behaviour during conversion processes such as combustion, gasification or liquefaction. The goal of utilizing the available large quantities of indigenous coal alone with reducing emissions is increasing the efficiency of power plants by utilizing steam conditions. The performance correlations based on bulk property analysis of coal adequately impact coal quality on conversion efficiencies and plant performance. Thermomechanical analysis, an advanced bulk analytical technique provides detailed thermal behaviour of ash relevant to power plant operations. The decrease in easily worked deposits, together with the decline in the availability of the better quality coals has resulted in a need for the development of blending techniques. Blending is now extensively practiced in the preparation of coals which involve blending of several different classes and / or grades of coals to produce blends which on carbonization will yield coke. Coal petrology is the study of organic materials which make up coal. The object of study is to identify in terms of reactive capabilities, each of the organic materials making up coal and an attempt to relate the reactive capabilities with the industrial applications of coal. Various tests are being designed to investigate the feasibility of Indian Coals in pulverized coal boilers.
\end{abstract}

Keywords - Petrography, Macerals, Thermogravimetric analysis, Microscopy, Design, Blending

\section{INTRODUCTION}

Journal on Today's Ideas Tomorrow's Technologies Vol. 1, No. 1 June 2013 pp. 1-14 to characterize. Coal is rock formed by geological processes and is composed of a number of distinct organic activities called macerals, and lesser amounts of inorganic substances - minerals. The essence of the petrographic approach to the study of coal composition is the idea that coal is composed of macerals, which each have a distinct set of physical and chemical properties that control the behaviour of coal.
CHITKARA UNIVERSITY

(C)2013 by Chitkara University. All Rights Reserved. 
Siddhartha Kumar, R.
As its methods were refined and its range of problems grew, coal petrography became concerned with the composition, structure, and origin of coals. In other words, it developed into the field of coal petrology. The principal task of coal petrology is the study of the elementary components of the organic matter of coal beds. These components are the remains of plants, which, in the process of biochemical decomposition into the peat stage of coal formation, lost or preserved to some extent of their form and structure. A distinction is made here between the tissue elements and the matrix, which, taken together, constitute the components of coal. Also, macrocomponents, such as vitrain and fusain, are distinguished from microcomponents, such as spores and cuticles.

\section{LITERATURE REVIEW}

Coal petrography employs various methods of investigation. In methods of optical microscopy, for example, the specimen may be viewed in air or in immersion; both transmitted-light and reflected-light methods are used, and the light may be ordinary, polarized, or ultraviolet. Specimens may be separated into groups of components of similar density in heavy liquids (mixtures, for example, of $\mathrm{C}_{6} \mathrm{H}_{6}, \mathrm{CCl}_{4}$, or $\mathrm{CHBr}_{3}$ ). Maceration methods are used to identify and then study stable components. Etching with strong oxidizers is employed to reveal the cryptographic structure of coal. Thermal and chemical analyses may be conducted of components or groups of components of coal samples. Quantitative methods are of great importance. They include the determination of the reflectance, refractive index, and hardness of vitrinite; the establishment of the color and brightness of luminescence of liptinite; and the calculation of the content of components in average bed samples and in chunks of coal.

From 14 to 40 petrographic components have been identified in coal by different investigators. Depending on the source material and the conditions of its transformation in the peat stage of coal formation, the micropetrographic components are classified into three basic groups (vitrinite, or gelinite; fusinite; and liptinite) and two intermediate groups (weakly gelified and weakly fusinized).

The composition of the source plants and the quantitative relations between micropetrographic components determine the genetic types of coal, which are characterized by definite chemical and technological properties within each stage of coalification. There are three basic groups of macerals, the vitrinite group derived from coalified woody tissue, the liptinite group derived from the

Journal on Today's Ideas - Tomorrow's Technologies (JOTITT), Volume 1, Number 1, June 2013 
resinous and waxy parts of plants and the inertinite group derived from charred and biochemically altered plant cell wall material.

\subsection{Vitrinite Macerals}

Vitrinite macerals are derived from the cell wall material (woody tissue) of plants, which are chemically composed of the polymers, cellulose and lignin. The inertinite macerals dominate in these coals[2].

\subsection{Matrix Vitrinite - Desmovitrinite}

Matrix vitrinite is almost always the most abundant maceral present and makes up the groundmass in which the various liptinite and inertinite macerals are dispersed. It has a uniform gray color and is always anisotropic. With ultraviolet excitation some normal vitrinite will fluoresce[2].

\subsection{Pseudovitrinite - Telovitrinite}

The most outstanding feature of pseudovitrinite is that it always has a slightly higher reflectance than the matrix vitrinite in the same coal. It also tends to occur in large particles that are usually free of other macerals and pyrite. Pseudovitrinite particles commonly show brecciated corners, serrated edges, wedge-shaped fractures, and slitted structures. Pseudovitrinite does not usually fluoresce with ultra-violet excitation[2].

\subsection{Liptinite Macerals}

The liptinite macerals are derived from the waxy and resinous parts of plants such as spores, cuticles, and resins, which are resistant to weathering and diagenesis. They have an abundance of liptinite macerals (sporinite in cannels and alginite in bogheads) and a paucity of vitrinite and inertinite macerals[2].

The outstanding petrographic feature of the liptinite group of macerals is that they all have a reflectance that is lower than the vitrinite macerals in the same coal. This group of macerals is very sensitive to advanced coalification and the liptinite macerals begin to disappear in coals of medium volatile rank and are absent in coals of low-volatile rank. When the liptinite macerals are present in a coal, they tend to retain their original plant form and thus they are usually "plant fossils" or phyterals. The phyteral nature of the liptinite macerals is the main basis on which they are classified.

Journal on Today's Ideas - Tomorrow's Technologies (JOTITT), Volume 1, Number 1, June 2013
Characterisation and Design

for Fossil Fuel

Fired Boiler in

Thermal Power

Plants. 
Siddhartha Kumar, R.

\subsection{Sporinite}

This is the most common of the liptinite macerals and is derived from the waxy coating of fossil spores and pollen. It generally has the form of a flattened spheroid with upper and lower hemisphere compressed until they come together. The outer surface of the sporinite macerals often shows various kinds of ornamentation. It should be noted that in sections that are parallel or near parallel to the bedding plane of the coal, the sporinite macerals will appear to take on a disc or oval shape that can be confused with resinite. In Paleozoic coals two sizes of spores are common. The smaller ones, usually $<100$ microns in size are called microspores and the larger ones ranging up to several millimeters in diameter are called megaspores. Sporinite is also classified on the basis of the thickness of the spore walls -- thin-walled (tenuispores) and thick- walled (crassispores). Spores formed in a sac (sporangium) on the original plants in which they were compressed into tetrahedral groups of four. Evidence of this formation can sometimes be seen under the microscope as a trilete scar on the surface of the sporinite[2].

\subsection{Cutinite}

While not very abundant, this maceral is commonly found in most coals and is derived from the waxy outer coating of leaves, roots, and stems. It occurs as long stringers, which often have one surface that is fairly flat, and another surface which is crenulated. Cutinite usually has a reflectance that is equal to that of sporinite. Occasionally the stringers of cutinite are distorted. Because cutinite occurs in sheet-like fragments and is very resistant to weathering, it is sometimes concentrated in weathered coals to which it gives a sheet-like appearance. Such coals are called paper coals[2].

\subsection{Resinite}

Resinite macerals are ubiquitous, though minor, components in most coals below medium- volatile bituminous rank. They are usually absent in coals of higher rank. This secondary resinite shows an intrusive relationship to the host coal and often shows flow texture and carries xenoliths of coal in resinite veinlets. Fluorescence microscopy reveals that only the primary resinite ovoids commonly show "oxidation" or "reaction rims" that suggest a surface alteration. Fluorescence spectral analysis can usually distinguish resinite from other macerals and in most cases it can also distinguish between different resinites[2]. 


\subsection{Intertinite Macerals}

The inertinite macerals are derived from plant material that has been strongly altered and degraded in the peat stage of coal formation[2].

The inertinite macerals have the highest reflectance of all the macerals and are distinguished by their relative reflectances and structures.

\subsection{Fusinite}

Fusinite is seen in most coals and has a charcoal-like structure. Fusinite is always the highest reflecting maceral present and is distinguished by celltexture. It is commonly broken into small shards and fragments[2].

\subsection{Semifusinite}

Semifusinite has the cell texture and general features of fusinite except that it is of lower reflectance. In fact, semi-fusinite has the largest range of reflectance of any of the various coal macerals going from the upper end of the pseudovitrinite range to fusinite. Semi-fusinite is also the most abundant of the inertinite macerals[2].

\subsection{Macrinite / Semimacrinite}

Macrinite is a very minor component of most coals and usually occurs as structureless ovoid bodies with the same reflectance as fusinite[2].

\subsection{Micrinite}

Micrinite occurs as very fine granular particles of high reflectance. It is commonly associated with the liptinite macerals and sometimes gives the appearance of actually replacing the liptinite[2].

\subsection{Sclerotinite}

Sclerotinite occurs as ovoid bodies with cell-structure, with reflectances covering the entire inertinite range.[2]

\subsection{COALUTILISATION}

Coal utilization leads to the following views :

(a) Conversion issues

(b) Operational issues

(c) Environmental issues.
Characterisation and Design for Fossil Fuel Fired Boiler in Thermal Power Plants. 
Siddhartha Kumar, R.

\subsection{Conversion Issues}

The various steps involved in conversion are preparation, conversion of coal to char / ash and eventually char combustion or gasification. The issues pertinent to the preparation require information on the physical properties of coal such as density, hardness and other mechanical properties of coal. Thermogravimetric analysis(TGA) changes in the mass of a sample are studied while the sample is subjected to a controlled temperature programme.[9] The temperature programme is most often a linear increase in temperature, but isothermal studies can also be carried out when the changes in the sample mass with time are followed.TGA is inherently quantitative and therefore an extremely powerful technique, but gives no direct chemical information. The ability to analyse the volatile products during a weight loss is of great value. Factors affecting TGA are as follows:

(a) Heating rate and sample size.

(b) Particle size and packing size.

(c) Crucible shape.

(d) Gaseous atmosphere.

Applications of TGA are as follows: TGA to generate fundamental quantitative data from almost any class of materials to its widespread use in every field of science and technology.

(a) Thermal stability: Related materials can be compared at elevated temperatures under the required atmosphere.

(b) Material characterization: TGA curves can be used to fingerprint materials for identification or quality control.

(c) Compositional analysis: By careful choice of temperature programming and gaseous environment, many complex materials or mixtures may be analysed by selectively decomposing or removing their components. This approach is regularly used to analyse e.g : filler content in polymers, carbon black in oils, ash and carbon in coals and the moisture content of many substances.

(d) Simulation of industrial processes: Thermobalance furnace may be thought of as a mini reactor with the ability to mimic the conditions in same types of industrial reactor.

(e) Kinetic studies: A variety of methods exist for analyzing the kinetic features of all types of weight loss or gain either with a view to predictive studies or to understanding the controlling chemistry. 
(f) Corrosion studies: TGA provides an excellent means of studying oxidation or reaction with other reactive gases or vapours.

Conversion issues are usually broken down into 2 steps : Pyrolysis and Char reactivity.

\subsubsection{Pyrolysis}

Devolatilisation coals of different types exhibit wide variations in their devolatilisation behaviour, because of different extents of coalification. The degree of aromatization in the coal structure increases with the increase in the rank of the coal.The information on maceral composition of coal is of paramount importance on the devolatilisation and char conversion issues. The primary physical changes that occur when any particular coal is heated depend on the melting and decomposition behaviour of the coal.Variables that influence devolatilisation rates include temperature, residence time, particle size and coal type and final temperature is possibly the most important one.

\subsubsection{Char Formation And Combustion}

The physical structure of coal including pore structure, surface area, particle size etc. is important in understanding and modeling combustion and char oxidation process. The conversion characteristics such as the calorific value, volatile and ash content and other physical property values provided by the bulk analysis of coal are required for a better design of a combustion pore size distribution system. Within char is probably one of the most important aspects of char character because the conversion of char takes place by the diffusion of gas through the pore into the char The most important issues related to char / ash are their movement through the boiler / gasifier and their deposition on various surfaces. These characteristics of char / ash depend on the structure of char / ash and its thermal and mechanical properties which inturn are strong functions of the maceral composition and the mineral matter present in the parent coal.

\subsection{Operational Issues}

The flame stability, erosion, slagging and fouling characteristics are important aspects in the determination of the efficiency of the conversion process. Flame instability and slagging / fouling may lead to enormous downtimes and therefore operational losses. Fouling and slagging occur because of the deposition of the ash on boiler surfaces. The molten ash then sinters and forms deposits that are difficult to remove. Elemental information and mineral

Journal on Today's Ideas - Tomorrow's Technologies (JOTITT), Volume 1, Number 1, June 2013
Characterisation and Design

for Fossil Fuel

Fired Boiler in

Thermal Power

Plants. 
Siddhartha Kumar, R. interactions of the parent coal provide important information regarding the propensity of a particular coal to form deposits. Analysis such as ash fusion temperature is conducted to understand the process of slagging / fouling. Thermomechanical analysis is being recommended as a better technique to assess thermal behaviour of coal ash in boilers. Instability in the flame can also lead to non uniform heat flux and incomplete conversion. The volatile matter in coal is used as a design parameter of the boiler to obtain a continuous flame. The estimate of Volatile Matter in a coal fired boiler at high flame temperatures is obtained by experiments in a drop tube furnace.

\subsection{Environmental Issues}

Coal utilization can be categorized into gaseous emissions such as oxides of nitrogen, fine particulates and GHG emissions. The GHG emission is more related to the efficient use of coal rather than properties of coal. With the increasing concern about the environmental impact of potentially hazardous trace elements from coal combustion, attention has been focused to the levels of these trace elements present in waste products released into the environment.[1]

\subsection{VITRINITE REFLECTANCE (VR)}

VR is a direct measure of the rank of coal and is known to be a major factor affecting its quality. Vitrinite reflectance is the amount of light that is reflected from vitrinite in a polished surface of a sample and can be measured by photometer or by the grey scale intensity in a high quality image. Maximum reflectance is the highest value of reflectance obtained when any polished section of a grain is rotated about an axis coincident with the optic axis of the microscope in plane polarized light.Mean random reflectance is the reflectance of a grain in the orientation that is encountered that is no rotation of the stage and measured using non - polarized light.

VR is widely used to assess the rank of particular coals and to measure the variation of rank with depth. Rank is an abstract concept which can be quantified only through the use of a changing property known as reflectance. Reflectance is used to identify the stage reached by the coal as it becomes progressively more mature in response to rising bed temperatures.Other properties such as moisture content or volatile matter yield can be and sometimes are used to characterise rank properties. Without knowing a coals rank it is difficult to interpret its properties. For example : a coal sample may be shown to have only limited swelling properties during carbonization, while this may result from the presence of a comparatively low content of vitrinite ; it may also result from 
the rank of the coal being lower or higher than optimum. It could also result from the coal being oxidized or having been altered by an igneous intrusion, so that the vitrinite has lost much of its former swelling power. In each of these cases, a knowledge of the coal rank makes it possible to understand the reason for the coals behaviour. Reflectance is widely used because it has proved a better parameter of rank than most others.[5]

\subsection{Electron Microscopy}

Very thin sections $(<0.1$ micron) are prepared for Transmission Electron Microscopy (TEM) examination using an ultramicrotome. Through careful isolation of material for sectioning and by monitoring the microtomed face after cutting it is possible to compare light and electron microscope images from the same field.With TEM high degrees of magnification and resolution can be obtained to provide information in the three or four orders of magnitude which lie between the lower limits of light microscope resolution and molecular levels. It has been found that at least qualitatively the TEM observations provide an explanation for many of the variations in vitrinite reflectance.

\subsection{Fluorescence Microscopy}

It is based upon the concept that ultraviolet or blue light is absorbed by certain organic functional groups and then readmitted at a higher wavelength. If the excitation light is filtered from the light path, then the surface can be expressed by an emission image based upon the organic chemistry of the material. Fluorescence intensity and spectral distribution are very sensitive to surface oxidation.Consequently, the techniques have been used to evaluate the quality and storage deterioration of coals and the thermal sensitivity of roadway asphalts. As both of these materials, become oxidized they lose their thermoplastic properties thus affecting their quality and service life.

\subsection{APPLICATION OF REFLECTANCE ANALYSIS}

The amount of light reflected from the surface of a humic substances contained in coal or dispersed in sediments provides a sensitive measure of rank or maturity in response to regional thermal history. When the photometer system is calibrated against standards of known reflectance, a distribution of reflectance values can provide a unique mean value for a given material. Reflectance analyses are used to predict the behaviour of a coal for the production of metallurgical coke ; to establish the quality and uniformity of coal products and to establish the maturity of sediments with regard to the

Journal on Today's Ideas - Tomorrow's Technologies (JOTITT), Volume 1, Number 1, June 2013
Characterisation and Design

for Fossil Fuel

Fired Boiler in

Thermal Power

Plants. 
Siddhartha Kumar, R. generation and migration of petroleum and gas. Consequently, the technique establishes a relationship between geologic history exploration and resource assessment. Because reflectance is strongly related to the aromatic structure of organic material, the technique has been used effectively to evaluate changes in carbonaceous materials during processing and for process optimization.[5]

\subsection{BOILER DESIGN FOR INDIAN COAL}

Design of a steam generator using Indian coals that are widely used for new power projects in India are generally low sulfur content and have a reduced likelihood of fireside corrosion problems. Low sulfur Indian coals are expected to have lower risk to fireside corrosion. However the ash content of Indian coals is very high and the silica / quartz content is very high thus very erosive requiring much lower gas velocities passing through the convection tube banks about $50 \%$ less than a higher grade US Coal. Special erosion protection provisions are also required on the pulverisers and boiler components. The impact to the design arrangement and cost is significant. The size of the gas flow area increases about $50 \%$ and the amount of heating surface increases due to lower heat transfer rates.

Compared to a boiler using US eastern bituminous coal, the furnace of a boiler using Indian coal is about $78 \%$ larger in volume and about 50\% taller. Lower furnace exit gas temperatures are specified. The furnace width is about $38 \%$ more impacting the length of the Ni alloy SH / RH outlet headers. Furnace wall average absorption rates are lower while the peak rates will be expected to be nearly the same. Staged firing for NOx reductions may be required at some plants. The lower furnace walls may be fabricated starting with lower chrome steel, T12 and T22 for the middle water walls.

Advanced Ultra Super Critical boilers upper water walls of the furnace will operate at about 55 degrees Centigrade higher temperature than current practice and there by require different material. At this higher temperature T92 tubing is preferred for wall construction and brings new welding procedures to the furnace erection requirements.

A vertical or spiral tube furnace enclosure may be used based on the steam flow to perimeter ratio. With Indian coal and its larger furnace perimeter requirements, a spiral design is used. The heating surface arrangement and steam temperature control method will need to result in component operating temperatures that change very little versus load. It is desirable not to have large magnitude changes in the material temperature of thick components like $\mathrm{SH}$

Journal on Today's Ideas - Tomorrow's Technologies (JOTITT), Volume 1, Number 1, June 2013 
and RH outlet headers. Rapid cyclic temperature changes will cause fatigue damage and reduce component life. The vertical steam separator is a thick wall component that must be located in the steam generator flow sequence considering the cyclic temperature changes of start up and load changing. The location will also impact the Benson point load where the Steam Generator will begin to operate in once through mode.

\subsection{COAL BLENDING}

Coal blending in power stations is mainly adopted to improve the quality of coal being fired. The low-grade coals can be mixed with better grade coal without deterioration in thermal performance of the boiler. Coal blending can be carried out at different points along the transport chain: at coal mines, at coal cleaning plants or at power plants. At the power plant blending can take place in stock piles, bins, bunkers, on belt conveyors or in separate grinding mills. Coal blend properties are calculated as weighted average of determined values for the individual coal used for blending. The volatile matter, moisture, ash, fixed carbon, carbon, hydrogen, sulphur, nitrogen, oxygen and maceral contents and heating values are additive. For blends between coals of widely differing ranks, the additive rule may not be $100 \%$ applicable for deciding the Volatile matter and ash content of blended coal based on VM and ash contents of constituent coals.Hence caution to be exercised while using additive properties of volatile matter and ash content. The ash fusion temperatures and Hard Grove Index are generally non-additive. Blending decisions should be based on the knowledge of the specific behavior of a given pair of coals, rather than an assumption of linear variation of properties with blend traction. To decide to blend or not, it is very important to understand the composition of the coals that are to be blended. This means one will have to understand the origin of coal, the organic and inorganic chemistry of coal, and the behavior of the coals in questions. Some interaction between the constituent coals can occur, especially in petrographically heterogeneous coals or coals with different ash chemistry which may not be desirable. It has been found from field data that even if the blended coal closely resembles the design coal for the boiler, the blend need not perform the same way. A blend that performs satisfactorily in one boiler will behave differently in another boiler of similar design, where operating conditions differ and in some cases, even in boiler of the same design blending can result in serious problems if the design coal and the coal use for blend are incompatible.

Journal on Today's Ideas - Tomorrow's Technologies (JOTITT), Volume 1, Number 1, June 2013
Characterisation and Design

for Fossil Fuel

Fired Boiler in

Thermal Power

Plants. 
Siddhartha Kumar, R.
This is mainly due to the transformation of inorganic particles during combustion and the way in which the organics are dispersed in coal. Coals are blended to alter their chemical characteristics. During this process some of the physical characteristics become undesirable. Blending hard and soft coals will lead to difficulty in pulverization. The pulveriser performance is likely to follow the harder coal. A limitation to blending coals is the compatibility of the coals themselves, and problems are more likely when blending petrographically different coals or coals with different ash chemistry. The presence of more inert macerals may reduce the combustion efficiency.

Some combinations of coal ash can produce low melting eutectics, affecting the slagging and fouling behavior. Non-additive properties make blend evaluation for power generation inherently complex. More work is required on understanding how the inorganic components of coals in the blend interact and how it affects ash behavior including its emissivity, reflectivity, and thermal conductivity.

Generally as the sulphur content decreases, fly ash resistivity increases, thereby decreasing the ESP collection efficiency. Similarly a reduction in $\mathrm{Fe}_{2} \mathrm{O}_{3}, \mathrm{~K}_{2} \mathrm{O}$ and $\mathrm{Na}_{2} \mathrm{O}$ or increase in $\mathrm{CaO}, \mathrm{MgO}$ and $\mathrm{SiO}_{2}$ will increase the flyash resistivity, affecting the ESP collection efficiency.

Thus Indian coal is being maintained and made available by the following strategies:

(i) As the ash content of the coal increases and the calorific value of the coal decreases the mass of coal which must be burned increases. This impacts the coal receipt systems, conveyors, crushers, silos, feeders, pulverisers, pipes and burners. The largest impact will be on the pulveriser, where an increased throughput cannot only lead to increased auxiliary energy requirements, increased maintenance and potential limitations on the maximum achievable load, but will also reduce the availability of the unit through more failures and a decrease in the maximum load that the unit can achieve with pulveriser out of service due to planned or unplanned maintenance[4].

(ii) As the ash content of the coal increases and the fuel burn rate increases the quantity of flue gas traveling through the steam generator increases. Coupled with the increase in ash content, this causes an increase in tube failures, impacting both maintenance and availability[4].

(iii) As the ash content of the coal increases and the fuel burn rate increases, the quantity of the ash that the bottom ash, flyash and precipitator or fabric filter systems must handle will increase. This increased level of 
usage will yield higher levels of erosion and move frequent cleaning and preventive repairs[4]

(iv) Coal ashes are made up of different levels of minerals and inorganic compounds, which can yield different levels of erosion throughout any part of the unit which must handle coal, fluegas or ash. Inaddition, differing levels of inorganic compounds contribute to very different levels of corrosion, especially in the high temperature regions of the furnace.[6]

\subsection{CONCLUSION}

Blending of coals is expected to grow in the years to come due to shortage in domestic coal production. Since the combustion aerodynamic environments of a boiler furnace could not be simulated in a lab, the results of the laboratory experiments are to be carefully extrapolated and wherever required, more elaborate field trials are to be conducted.

Compatibility of coals for blending would have to be assured and blending with coals with large variation from design coal may pose performance problems. Lab scale evaluation of blended coals could be carried out to decide the limit of blending ratio. This could be followed by field trial starting from $10 \%$ of imported coal with incremental steps of $5 \%$.

Design elevation heat loading and/or minimum air flow limit the blending ratio. Adequate care should be exercised before increasing the percentage of blending to realize the benefits of coal blending. While blending, it is necessary to ensure uniform blending to have homogeneous mixture of the two coals being blended and accordingly blending arrangements are to be done preferably in CHP. Primary / Secondary air proportion needs to be adjusted during the trials to have better burner performance. Proper care is to be taken for storage of imported coal in yard to avoid spontaneous ignition if high volatile matter is present in the coal.

Fuel savings through improved boiler efficiency, improved combustion efficiency, improved pressure and superheat control, less slagging, less NOx through better control of excess air, less corrosion, stability and improved response of combustion controls, reduced operation and maintenance costs, improved coal mill performance and safety. [3] While there is uniformity in the generic design of industrial boilers they can differ due to factors such as the type of coal fired, efficiency and the size of the boiler and fuel feed systems. Pre and post combustion control techniques differences lead to difference in exhaust emissions. Efficiency measures that exist for
Characterisation and Design

for Fossil Fuel

Fired Boiler in

Thermal Power

Plants. 
Siddhartha

Kumar, R. boilers and distribution systems include maintenance, improved insulation, combustion controls and leak repairs in the boiler, improved steam traps and condensate recovery.

\subsection{REFERENCES}

[1]. Advanced Coal Characterization: A Review www.aseanenergy.info/Abstract/31026601.pdf http://dx.doi.org/10.1021/ef060411m

[2]. http://mccoy.lib.siu.edu/projects/crelling2/atlas/macerals/mactut.html, "Coal macerals tutorial".

[3]. "Pure and Applied Chemistry", Volume 49, pp. 1465 - 1473, Pergarnon Press, 1977. http://dx.doi.org/10.1351/pac197749101465

[4]. "Report of the group for studying range of blending of imported coal with domestic coal", Central Electricity Authority, New Delhi, April 2012.

[5]. Suarez - Ruiz Isabel, "Organic Petrology : An overview”. http://dx.doi.org/10.5772/23431

[6]. Vikas Chawla, Amita Chawla, et al., "Hot Corrosion and Erosion problems in coal based power plants in India and possible solutions - A review", Vol. No. 10, No. 4, pp. 367-385, JMMCE. org, 2011. 